\title{
LABORATORY STUDY OF THE BEHAVIOR OF PILE GROUP SUBJECTED TO LATERAL LOADS IN SANDY SOIL
}

\author{
M. A. Mahmoud \\ Lecturer, Civil Engineering Department, Helwan University, Cairo, Egypt \\ E. A. Hassan \\ Assistant Lecturer, Civil Engineering Department, Helwan University, Cairo, Egypt \\ A. M. Radwan \\ Professor, Civil Engineering Department, Helwan University, Cairo, Egypt

\begin{abstract}
This study is concerned with identifying the deflection of pile groups subjected to lateral load and the corresponding soil failure. A digital photogrammetric system is adopted for studying the field deformations. A wide range of studies was carried out to investigate the effect of some parameters on the behavior of the pile group. These parameters are effect of spacing between piles, number of piles, piles slenderness ratio and soil density. Using the experimental model results, relations were deduced to estimate the lateral deflection of pile group. A comparison is done between these relations and some relations given in the literature.
\end{abstract}

Keywords: pile group, field deformation, digital photogrammetry and lateral loads.

Cite this Article: M. A. Mahmoud, E. A. Hassan and A. M. Radwan, Laboratory Study of the Behavior of Pile Group Subjected to Lateral Loads in Sandy Soil. International Journal of Civil Engineering and Technology, 11(1), 2020, 266-278.

http://iaeme.com/Home/issue/IJCIET?Volume=11\&Issue=1

\section{NTRODUCTION}

Lateral loads are imposed on soil from structures by several sources such as earthquake, wind, impact. Design of foundations for structures subjected to lateral loads is a principal issue in the geotechnical engineering design. Deep foundations are widely used to support the laterally loaded structures. Safety against geotechnical failure, structural failure and excessive deflections are to be taken into consideration in the design of both single pile and pile groups where lateral loads are expected.

This paper is concerned with identifying the deflection of pile groups subjected to a lateral load and the soil failure as a result of this load. 
A digital photogrammetric system is adopted for studying the deformation field. The experimental program is presented together with a full description of the used soil and model tank.

The tank used in the model tests is $60 \mathrm{~cm}$ long, $60 \mathrm{~cm}$ high and $40 \mathrm{~cm}$ wide, so that the tank boundaries do not interfere with the development of the strain field in the soil. Piles 2.5 $\mathrm{cm}$ diameter with different lengths of $25,30,35$ and $40 \mathrm{~cm}$ were used to study the effect of length to diameter ratio (L/D). 2.5D and 3D spacing between piles were used also in the current study. 2 and 3 number of piles were used in the current study. The sand used in the experimental program has densities 18.6 and $17.7 \mathrm{kN} / \mathrm{m}^{3}$.

\section{PHOTOGRAMMETRY TECHNIQUES FOR MEASURING SOIL FIELD DEFORMATIONS}

The photogrammetry techniques have been developed through several stages. First the deformations were directly measured through measuring devices embedded in the soil (Allersma, 1996) [1], which experienced several errors. Then, it was improved to taking photographs for the soil body before and after deformation, which also faced the problem of focusing and other problems. The technique was then upgraded by using X-ray, but the rays were diverged (Andrawes and Butterfield 1973) [2]. Then, the stereo-photogrammetry was applied (Butterfield et al, 1970) [4]. In this technique a pair of photographs, including a relative displacement of the soil particles with respect to a fixed object, are viewed together with a stereo-viewer. The 3-dimensional pattern which the human eye identifies and the corresponding measurements are used to obtain the displacement of any point in the displacement field. However, according to (Ticof 1977) [9] there were several disadvantages in this method (movement of the camera during successive photographs, measurement of the parallaxes with the stereo plotter, distortion of the film, and others). Finally, it was decided that the best solution, up till now, is the digital photogrammetry (white et al, 2003) [10]; the technology that may be called pixel photogrammetry. The technique of digital photogrammetry was adopted herein, (Attia, 2013) [3]. A digital camera was placed in a fixed position during all the tests. Photos were captured before and after loading. A remote control was used to avoid any movement of the camera. After that the photos were downloaded to a computer and inserted in software to determine the deformations of each tracing point in the photos before and after loading. The deformations were compared with those obtained by applying theoretical solutions. The case of rigid sand-gravel layer topping a lesser rigid sand layer was studied. The obtained results were compared with the results of field plate load tests on two-layered soil giving reasonable agreement.

\section{SOIL AND EXPERIMENTAL WORK}

\subsection{Soil Used in Model Tests}

Cohesionless soil samples were used in this study. The properties of this soil can be summarized as follows: table 1 . 
Table 1. Properties of soil used in model tests

\begin{tabular}{|c|c|}
\hline Specific gravity (Gs) & 2.56 \\
\hline \multicolumn{2}{|l|}{ Case 1} \\
\hline Maximum bulk density (kN/m3) & 20.34 \\
\hline Optimum moisture content $\%$ & 9.36 \\
\hline Maximum dry density $(\mathrm{kN} / \mathrm{m} 3)$ & 18.6 \\
\hline \multicolumn{2}{|l|}{ Case 2} \\
\hline Maximum bulk density $(\mathrm{kN} / \mathrm{m} 3)$ & 20.2 \\
\hline Optimum moisture content $\%$ & 10.5 \\
\hline Maximum dry density ( $\mathrm{kN} / \mathrm{m} 3)$ & 17.7 \\
\hline
\end{tabular}

The tested sand was clean well graded sand. Fig.1 shows the grading characteristics of used sand.

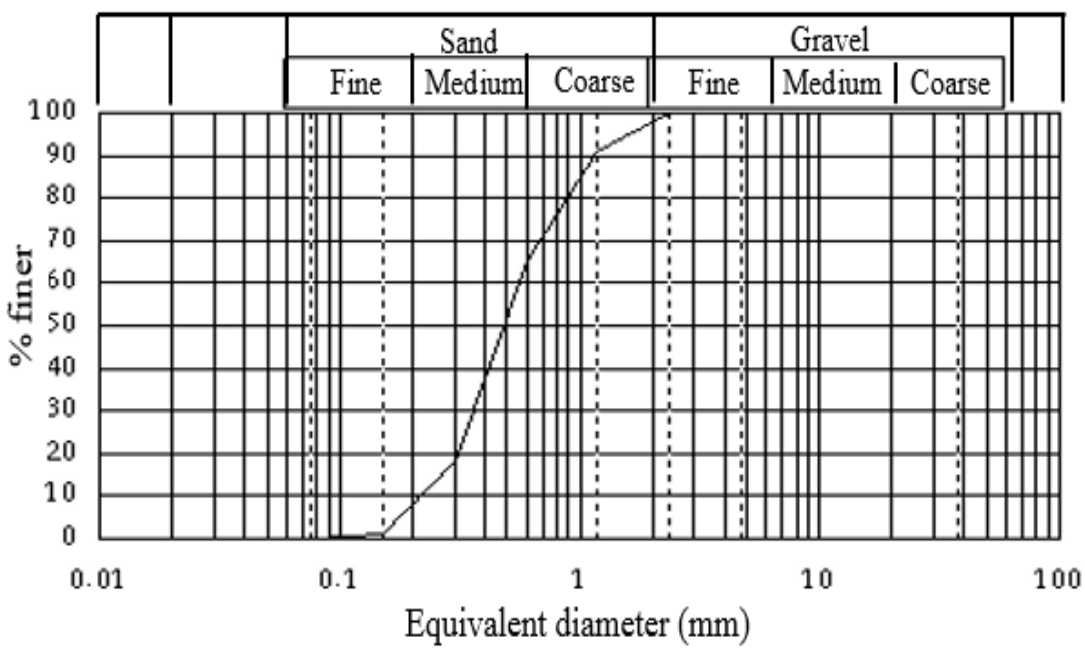

Figure 1. Grading characteristics of the used sand

\subsection{Tank Model}

As mentioned before, the dimensions of the container were $60 * 40 \mathrm{~cm}$ in plan and $60 \mathrm{~cm}$ depth. These dimensions were assumed to be big enough to minimize the effect of the boundary on the test results with respect to the dimensions of the model pile group, Fig. 2, (Hirayama, 1988; Rao et al. 1998) [7, 8].
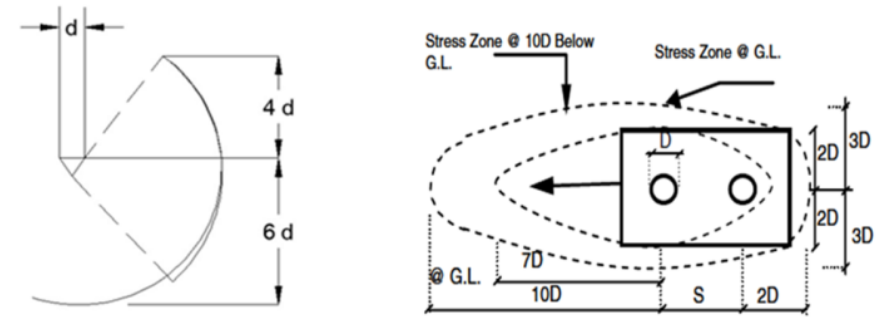

Figure 2. Influence zone under the pile (Hirayama, 1988), and around the pile group (Rao et al. 1998) 


\subsection{Pile Group Model}

The pile was made of polypropylene, $2.5 \mathrm{~cm}$ diameter were used. Four slenderness ratios (L/ d) were chosen in this research: 10,12, 14 and 16. The pile cap was made of wood to form a good bond with piles. The piles used in loading were half sections to be able to see the deformations of soil at the center level of piles. Fig. (3).

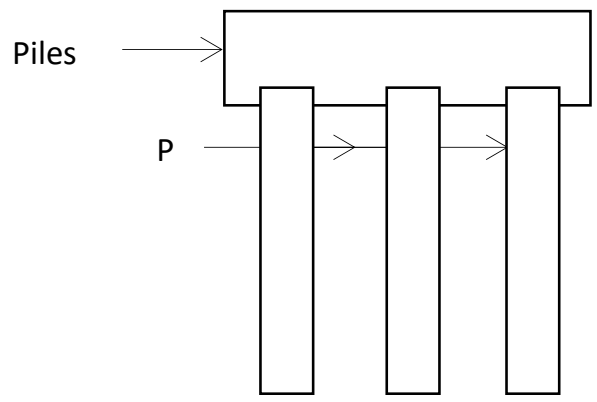

Figure 3. Piles setting in tank

\subsection{Loading System}

The loading system is shown in Fig. 4. This system was designed to be rigid and capable of sustaining the high stresses involved without suffering from excessive deflections.

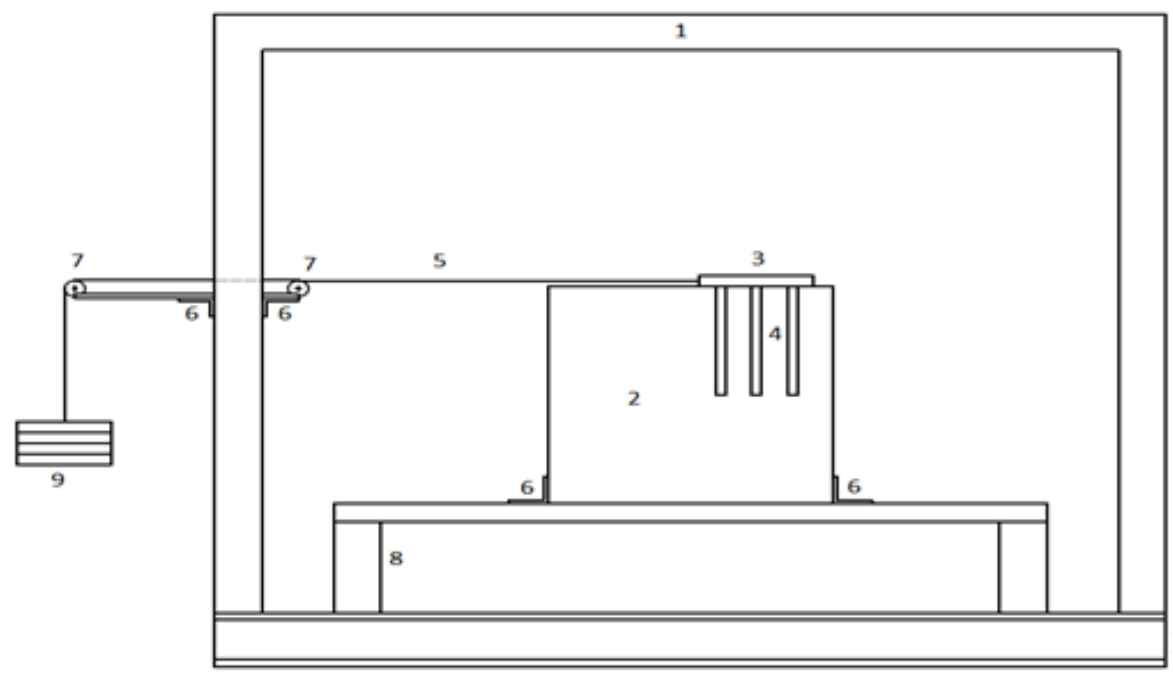

Figure 4. Loading system

\begin{tabular}{|l|l|}
\multicolumn{2}{c}{ Legend } \\
\hline 1 & Test frame \\
\hline 2 & Test tank \\
\hline 3 & Pile cap \\
\hline 4 & Piles \\
\hline 5 & Wire \\
\hline 6 & Angle \\
\hline 7 & Ring \\
\hline 8 & Steel base \\
\hline 9 & Loads \\
\hline
\end{tabular}




\subsection{Method of Measurement}

The horizontal load acting on the pile cap was measured by means of a proving ring having a capacity of $100 \mathrm{kN}$. A high quality digital camera was used in this study. Photographs were taken from a distance of $1.2 \mathrm{~m}$ from the face of the tank.

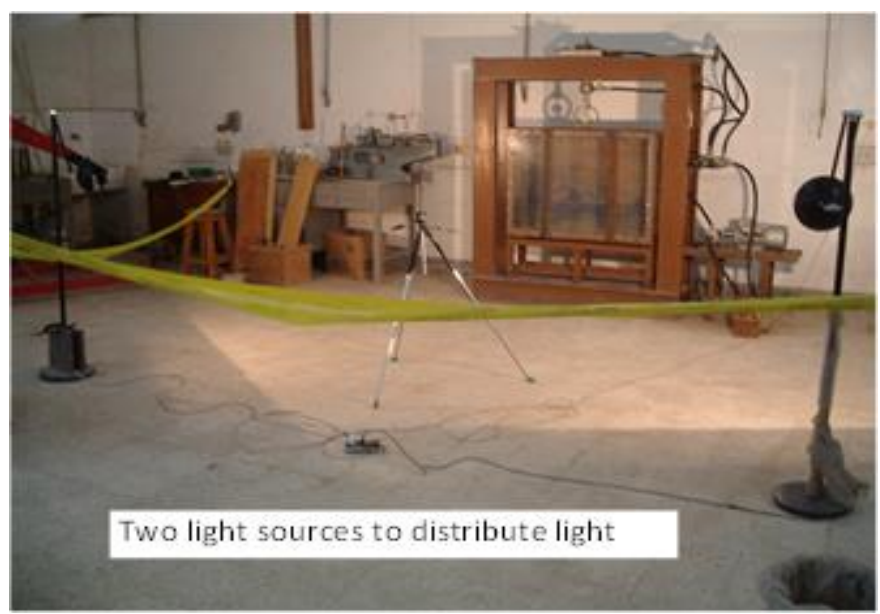

Figure 5. The tank, the loading frame, the camera

The camera was adjusted so that the photographic plane of the camera lens was parallel to the face of the tank. The camera was rigidly fixed and kept in position during the whole duration of the test. To avoid distortion of photos, shots were taken using a remote control. The light was provided by two tungstrum photographic lamps 500 watts each inclined $45^{\circ}$ to the face of the tank. Fig. 5.

\subsection{Sample Preparation and Testing Program}

According to the testing program, thirty two tests on pile group were carried out. The different conditions of the tests are shown in Table (2).

The following method is used:

- Firstly, the upper part of the tank is closed with a steel plate of dimensions equal to the whole cross-sectional area of the tank in plane minus from it the width of pile cap, and with depth 2 $\mathrm{cm}$.

- The Perspex plate is removed, and the model is placed on the crane in a horizontal position.

- Knowing the volume of the soil and its density, the required weight of each density of soil to be placed in the model is calculated.

- The calculated weight of sand is placed in five layers. Each layer was dynamically compacted by means of a compaction rod weighing 4.5kg over the whole area as shown in Fig. 6 .

- The surface of the soil is leveled using a straight wooden rod.

- The place of piles was drilled and the soil is well compacted under piles and next to them.

- The piles are set in their place and the soil is leveled.

- Colored small spheres, $10 \mathrm{~mm}$ diameter, with pins, $10 \mathrm{~mm}$ long as shown in Fig. 7, are placed in the center between piles on one row and two rows next to leading pile, to take their positions on the soil surface with the pins penetrating the soil.

- The Perspex plate was placed carefully in its position.

- The tank is adjusted to its base carefully in a vertical position by the second crane.

- The tank is set in its place on the base of the frame.

- The camera is positioned parallel to the face of the tank at a distance of $1.2 \mathrm{~m}$.

- Camera shots were taken to represent the initial condition of test.

- The lateral force is applied as shown in Fig. 4.

- The increments of loading of $4 \mathrm{~kg}$ are applied to the pile cap while monitoring. 
- Photographs of the model are taken every other incremental load for tracing points as shown in Fig. 8.

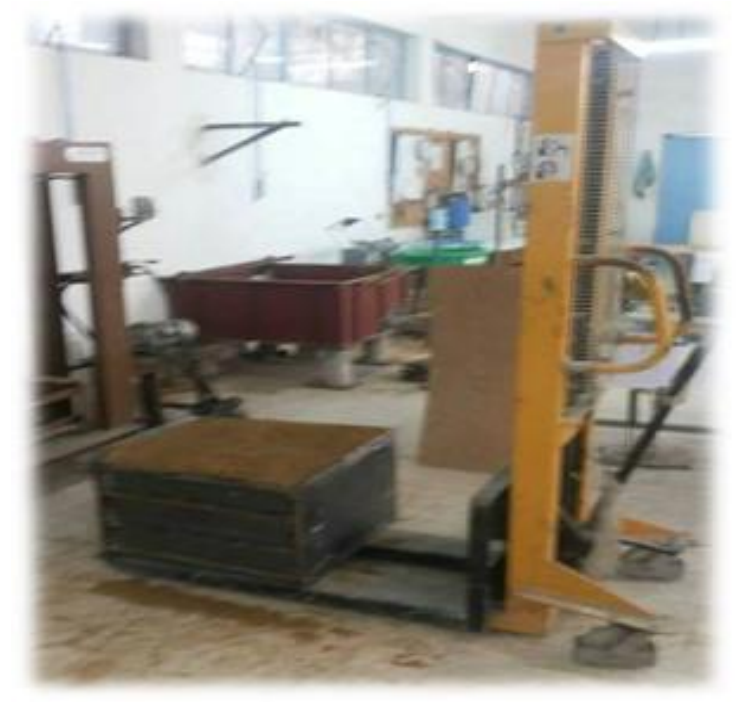

Figure 6. The soil in the model after compaction

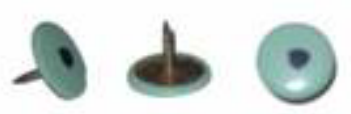

Figure 7.Coloured tracing point

Table 2. Test program

\begin{tabular}{|c|c|c|c|c|c|c|c|c|}
\hline Group & test & $\mathrm{L}(\mathrm{cm})$ & $\mathrm{D}(\mathrm{cm})$ & $\mathbf{L} / \mathbf{D}$ & $\begin{array}{c}\mathrm{S} \\
(\mathrm{cm})\end{array}$ & $\mathbf{N}$ & $\begin{array}{c}\gamma \text { dry } \\
\left(\mathbf{k N} / \mathbf{m}^{3}\right)\end{array}$ & Wc $\%$ \\
\hline \multirow{4}{*}{ A } & 1 & 25 & 2.5 & 10 & 6.25 & $3 \times 1$ & 18.6 & 9.36 \\
\hline & 2 & 30 & 2.5 & 12 & 6.25 & $3 \times 1$ & 18.6 & 9.36 \\
\hline & 3 & 35 & 2.5 & 14 & 6.25 & $3 \times 1$ & 18.6 & 9.36 \\
\hline & 4 & 40 & 2.5 & 16 & 6.25 & $3 \times 1$ & 18.6 & 9.36 \\
\hline \multirow{4}{*}{ B } & 1 & 25 & 2.5 & 10 & 7.5 & $3 \times 1$ & 18.6 & 9.36 \\
\hline & 2 & 30 & 2.5 & 12 & 7.5 & $3 \times 1$ & 18.6 & 9.36 \\
\hline & 3 & 35 & 2.5 & 14 & 7.5 & $3 \times 1$ & 18.6 & 9.36 \\
\hline & 4 & 40 & 2.5 & 16 & 7.5 & $3 \times 1$ & 18.6 & 9.36 \\
\hline \multirow{4}{*}{$\mathrm{C}$} & 1 & 25 & 2.5 & 10 & 6.25 & $2 \mathrm{x} 1$ & 18.6 & 9.36 \\
\hline & 2 & 30 & 2.5 & 12 & 6.25 & $2 \times 1$ & 18.6 & 9.36 \\
\hline & 3 & 35 & 2.5 & 14 & 6.25 & $2 \mathrm{x} 1$ & 18.6 & 9.36 \\
\hline & 4 & 40 & 2.5 & 16 & 6.25 & $2 \times 1$ & 18.6 & 9.36 \\
\hline \multirow{4}{*}{ D } & 1 & 25 & 2.5 & 10 & 7.5 & $2 \times 1$ & 18.6 & 9.36 \\
\hline & 2 & 30 & 2.5 & 12 & 7.5 & $2 \times 1$ & 18.6 & 9.36 \\
\hline & 3 & 35 & 2.5 & 14 & 7.5 & $2 \times 1$ & 18.6 & 9.36 \\
\hline & 4 & 40 & 2.5 & 16 & 7.5 & $2 \mathrm{x} 1$ & 18.6 & 10.5 \\
\hline \multirow{4}{*}{ E } & 1 & 25 & 2.5 & 10 & 6.25 & $3 \times 1$ & 17.7 & 10.5 \\
\hline & 2 & 30 & 2.5 & 12 & 6.25 & $3 \times 1$ & 17.7 & 10.5 \\
\hline & 3 & 35 & 2.5 & 14 & 6.25 & $3 \times 1$ & 17.7 & 10.5 \\
\hline & 4 & 40 & 2.5 & 16 & 6.25 & $3 \times 1$ & 17.7 & 10.5 \\
\hline \multirow{4}{*}{$\mathrm{F}$} & 1 & 25 & 2.5 & 10 & 7.5 & $3 \times 1$ & 17.7 & 10.5 \\
\hline & 2 & 30 & 2.5 & 12 & 7.5 & $3 \times 1$ & 17.7 & 10.5 \\
\hline & 3 & 35 & 2.5 & 14 & 7.5 & $3 \times 1$ & 17.7 & 10.5 \\
\hline & 4 & 40 & 2.5 & 16 & 7.5 & $3 \times 1$ & 17.7 & 10.5 \\
\hline \multirow{4}{*}{$\mathrm{G}$} & 1 & 25 & 2.5 & 10 & 6.25 & $2 \mathrm{x} 1$ & 17.7 & 10.5 \\
\hline & 2 & 30 & 2.5 & 12 & 6.25 & $2 \times 1$ & 17.7 & 10.5 \\
\hline & 3 & 35 & 2.5 & 14 & 6.25 & $2 \times 1$ & $\begin{array}{l}17.7 \\
\end{array}$ & 10.5 \\
\hline & 4 & 40 & 2.5 & 16 & 6.25 & $2 \times 1$ & 17.7 & 10.5 \\
\hline \multirow{4}{*}{$\mathrm{H}$} & 1 & 25 & 2.5 & 10 & 7.5 & $2 \times 1$ & 17.7 & 10.5 \\
\hline & 2 & 30 & 2.5 & 12 & 7.5 & $2 \mathrm{x} 1$ & 17.7 & 10.5 \\
\hline & 3 & 35 & 2.5 & 14 & 7.5 & $2 \times 1$ & 17.7 & 10.5 \\
\hline & 4 & 40 & 2.5 & 16 & 7.5 & $2 \times 1$ & 17.7 & 10.5 \\
\hline
\end{tabular}


Where;

$\mathrm{L}=$ pile length.

$\mathrm{D}=$ pile diameter.

$\mathrm{S}=$ spacing between piles.

$\mathrm{N}=$ number of piles.

$\gamma_{\text {dry }}=$ soil dry density.

$\mathrm{W}_{\mathrm{c}}=$ water content.

\section{PILE GROUP DEFLECTION}

\subsection{Effect of Length}

The deflection of pile groups subjected to a lateral load and the soil deformation as a result of this load were calculated from the photo before and after each loading stage, where spacing, number of piles and soil density are constant, the lengths $25,30,35,40 \mathrm{~cm}$ were used.

Load-deflection curves were drawn in eight Groups.

Fig. 9 shows the variation of deflections versus the slenderness ratio. The same trend was noticed for the other experiments. It is clear that increasing of slenderness ratio of piles increases the pile group deflection especially slenderness ratio of 16 for soil density 17.7 $\mathrm{kN} / \mathrm{m}^{3}$. These studies were summarized as shown in Fig.10.Sometimes, the piles with small slenderness collapse faster than the piles with large slenderness.

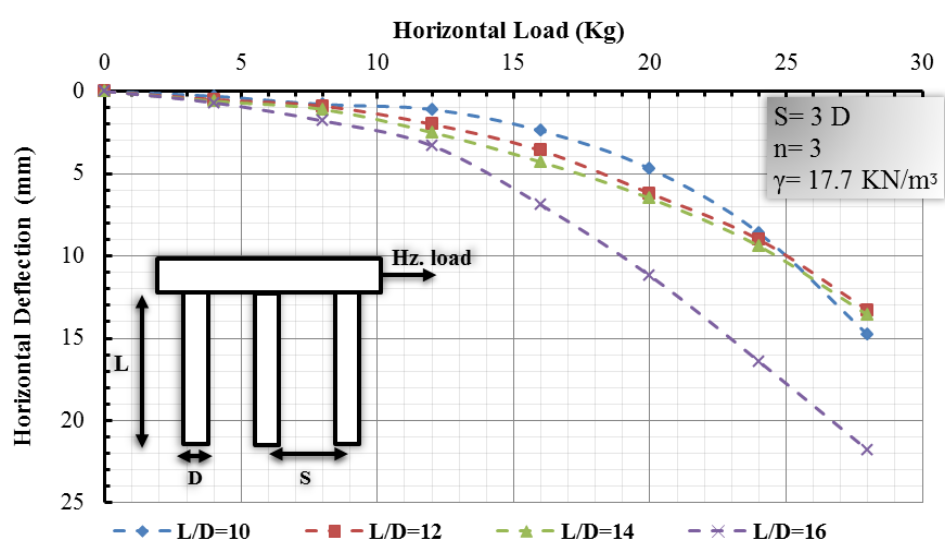

Figure 9. Load-deflection curve for spacing between piles $=3 \mathrm{D}$, number of piles $=3$, soil density $=$ $17.7 \mathrm{kN} / \mathrm{m}^{3}$, slenderness ratio $10,12,14$ and 16

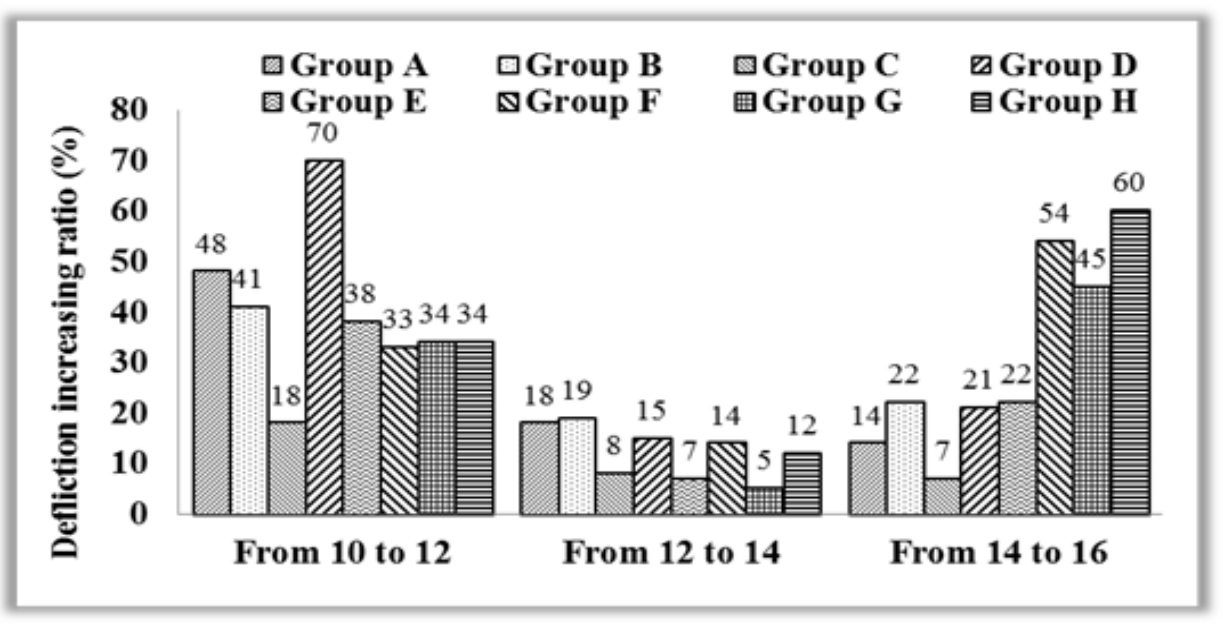

Figure 10. Increasing pile group deflection ratios for variable length 


\subsection{Effect of Number of Piles}

The deflection of pile groups subjected to a lateral load and the soil deformation as a result of this load were calculated from the photo before and after each loading stage, where spacing, length of piles and soil density are constant 2 and 3 piles were used. Fig.11. shows that increasing of number of piles decreases the pile group deflection. It is noticed that the deflection values are nearby at the spacing between piles was 3D and the values of deflections are spaced at the spacing between piles $2.5 \mathrm{D}$, for all slenderness ratio except for $\mathrm{L} / \mathrm{D}=16$. These studies were summarized as shown in Fig.12.
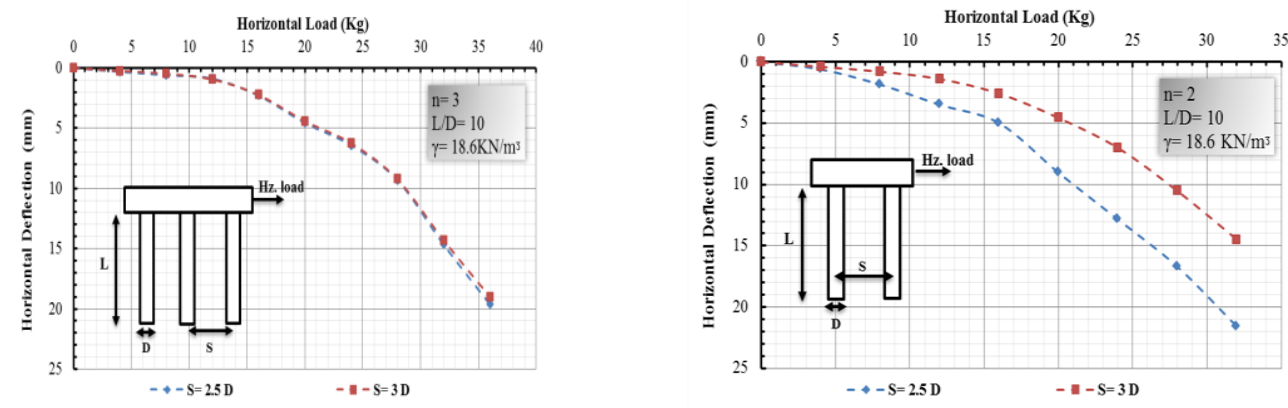

Figure 11. Load-deflection curve for $\mathrm{L} / \mathrm{D}=10$, dry density $=18.6 \mathrm{kN} / \mathrm{m}^{3}$ and spacing between piles is $2.5 \mathrm{D}$ and $3 \mathrm{D}$

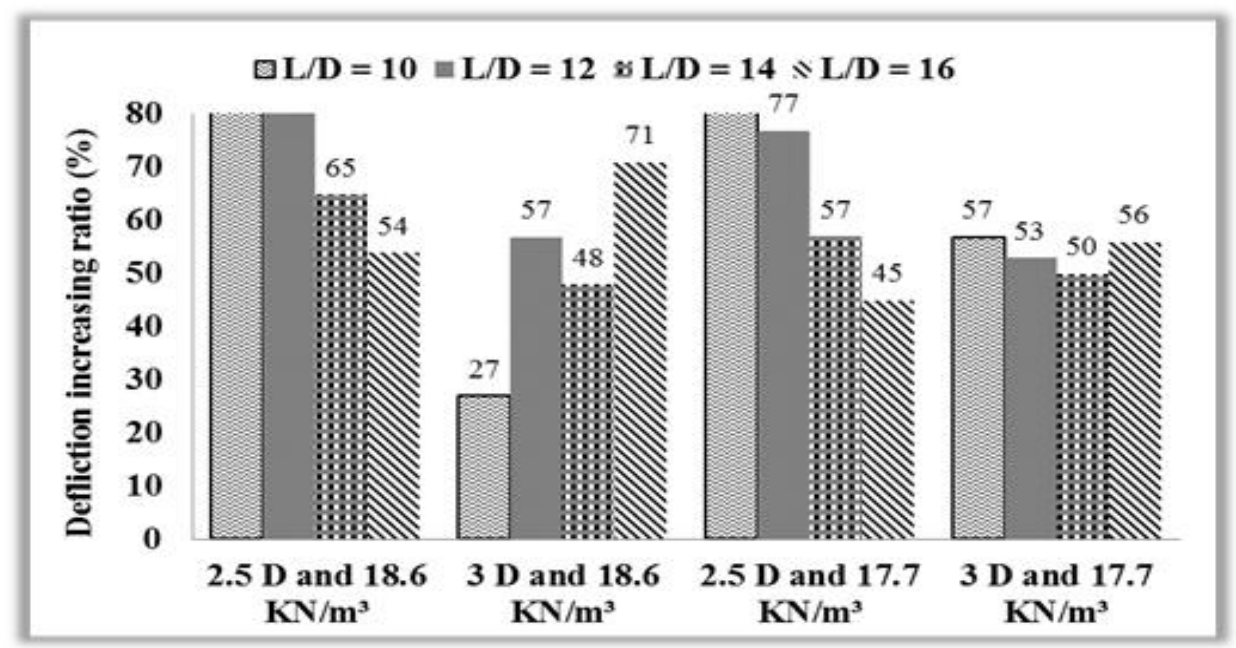

Figure 12. Increasing pile group deflection ratios for variable number of piles

\subsection{Effect of Spacing between Piles}

Keeping the number of piles, length of piles and soil density constants, 2.5D and 3D spacing between piles were used. Fig.13. Shows that increasing of spacing between piles decreases the pile group deflection. It is noticed that the deflection values are nearby at a number of piles of 3 and the values of deflections are spaced at a number of piles of 2, for all slenderness ratio except for $\mathrm{L} / \mathrm{D}=16$. These studies were summarized as shown in Fig.14. 

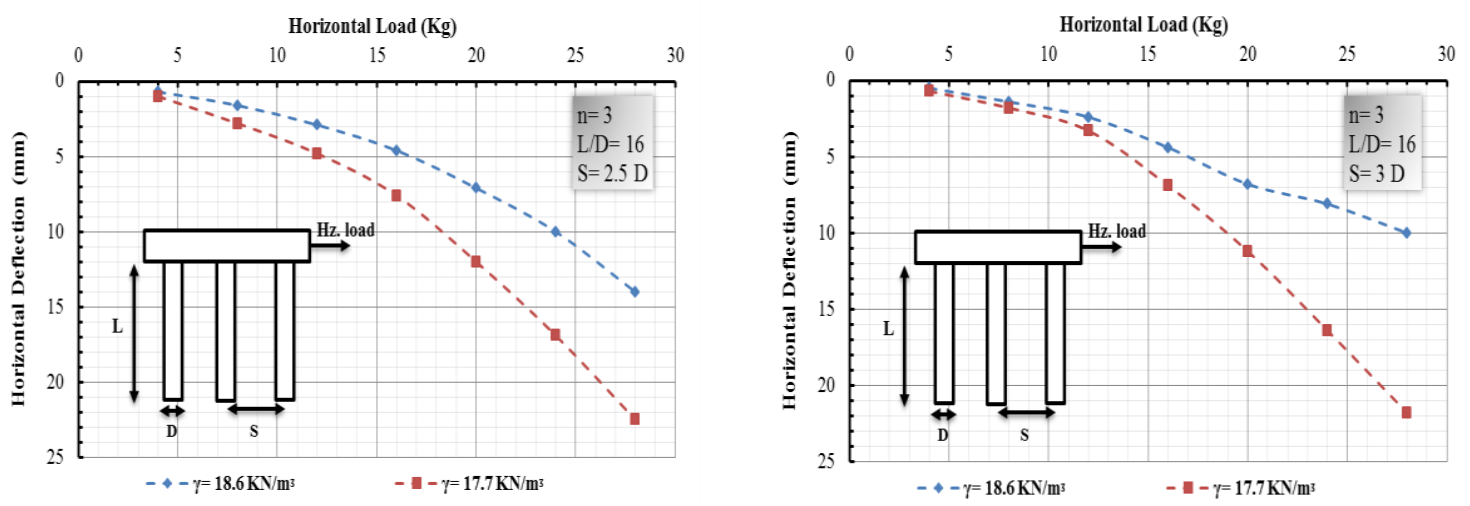

Figure 13. Load-deflection curve for $\mathrm{L} / \mathrm{D}=10$, dry density $=18.6 \mathrm{kN} / \mathrm{m}^{3}$ and number piles is 3 and 2

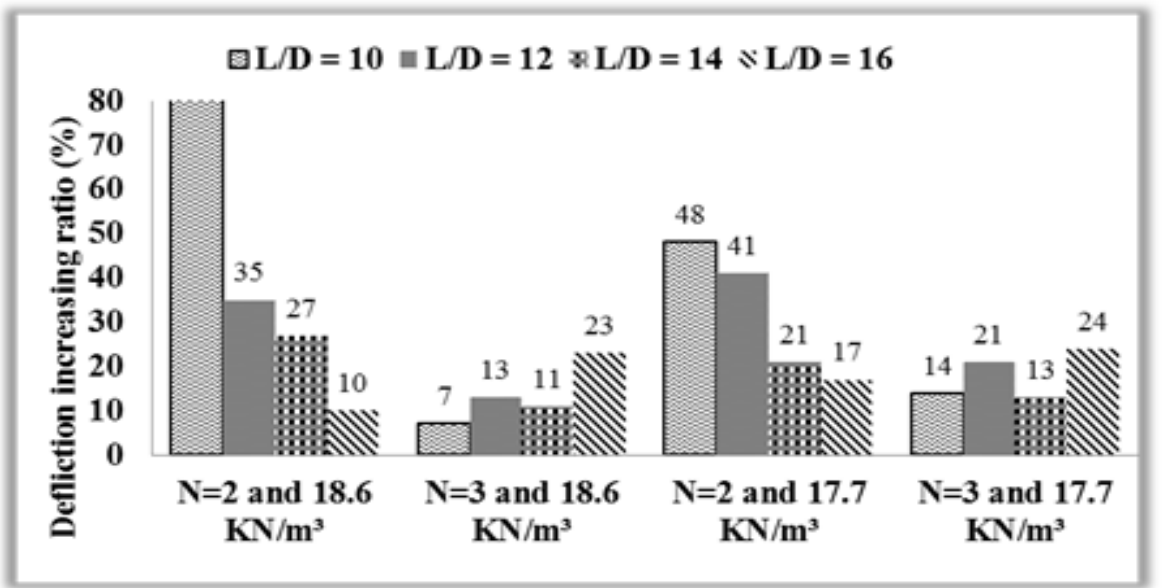

Figure 14. Increasing pile group deflection ratios for variable spacing between piles

\subsection{Effect of Soil Density}

Keeping the number of piles, spacing between piles and length of piles constants, sand dry densities $18.6 \mathrm{kN} / \mathrm{m}^{3}$ and $17.7 \mathrm{kN} / \mathrm{m}^{3}$ were used, Fig. 15 shows that increasing soil density decreases the pile group deflection. From $18.6 \mathrm{kN} / \mathrm{m}^{3}$ to $17.7 \mathrm{kN} / \mathrm{m}^{3}$ increases the pile group deflection a ratio of $64 \%$. Spacing between piles of $3 \mathrm{D}$, increases the pile group deflection with the same ratio
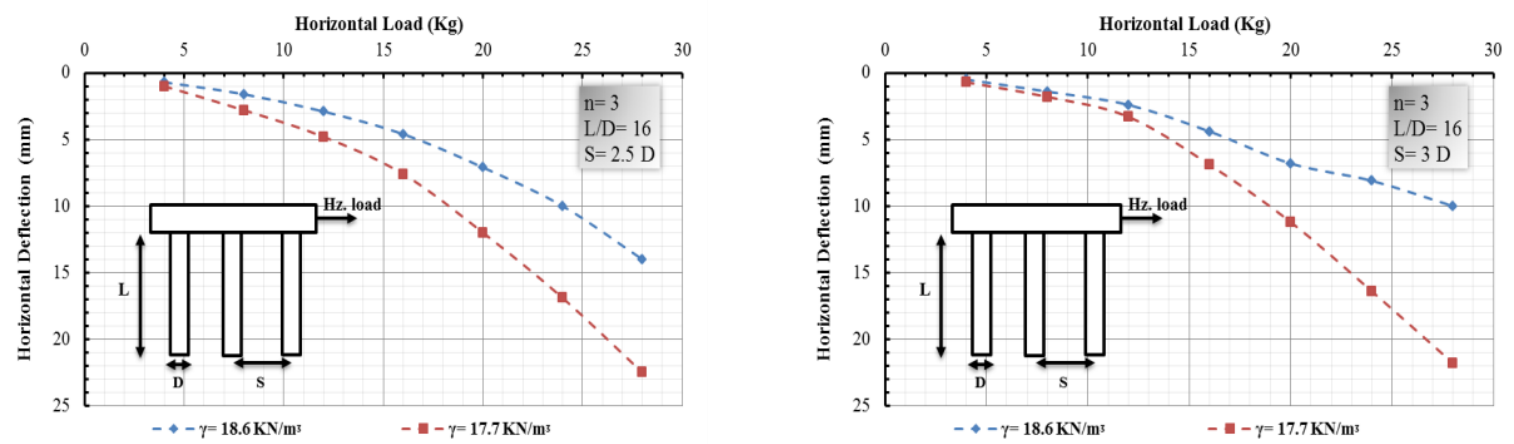

Figure 15. Load-deflection curve for $\mathrm{L} / \mathrm{D}=16$, number of piles $=3$ and Spacing between piles $=2.5 \mathrm{D}$ and $3 \mathrm{D}$ 
It is noticed that decreasing the soil density from $18.6 \mathrm{kN} / \mathrm{m}^{3}$ to $17.7 \mathrm{kN} / \mathrm{m}^{3}$ for $\mathrm{L} / \mathrm{D}=16$ and spacing between piles of $2.5 \mathrm{D}$, increases the pile group deflection with ratio of $64 \%$. For spacing between piles of 3D, this increases the pile group deflection with the same ratio. These studies were summarized as shown in Fig.16.

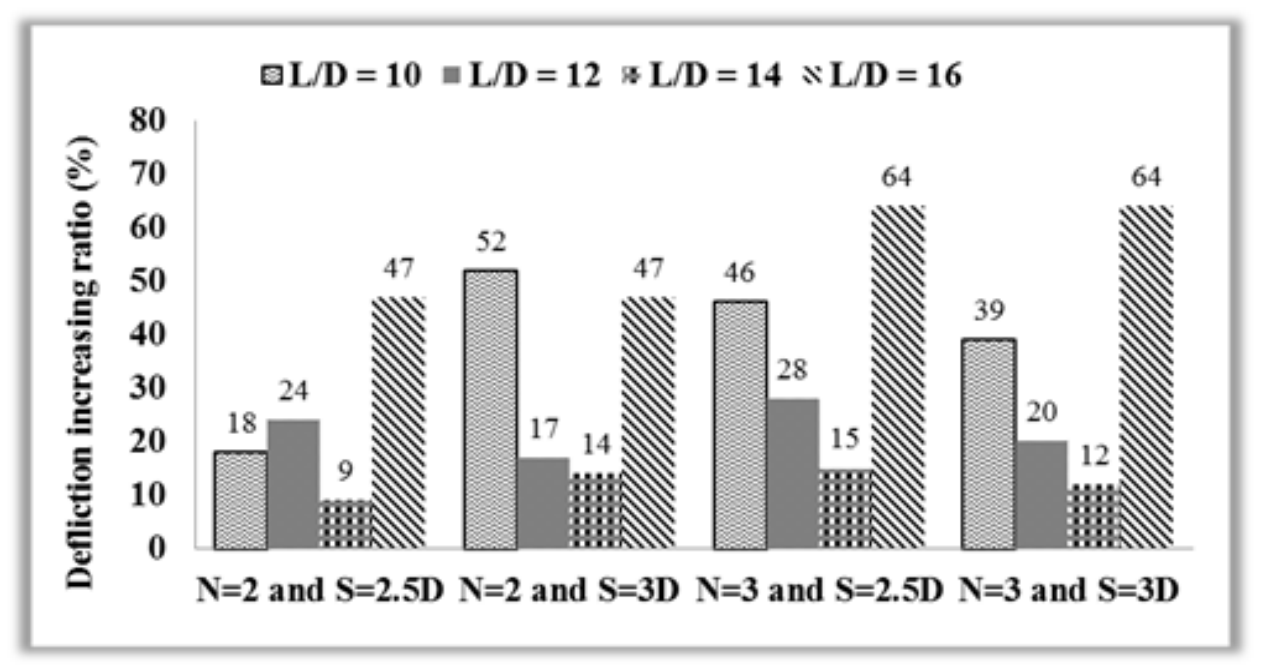

Figure 16. Increasing pile group deflection ratios for variable soil density

\section{COMPARISONS}

Evans and Duncan (1982) [5] defined the characteristic shear load. The deflection of pile group can then be obtained from a curve. The characteristic load method (CLM) is a modification of the Evans and Duncan's method (1994) [4]. The deflection of pile group can be obtained from the same curve of Evans and Duncan.

A comparison is made between Evans and Duncan's method, characteristic load method and the present study for cases of $\mathrm{L} / \mathrm{D}=14$, number of piles $=2$, spacing between piles $=3$ and Dry density $=17.7 \mathrm{kN} / \mathrm{m}^{3}$ as shown in Fig. 17 and for $\mathrm{L} / \mathrm{D}=16$, number of piles $=3$, spacing between piles $=3 \mathrm{D}$, dry density $=17.7 \mathrm{kN} / \mathrm{m}^{3}$ as shown in Fig.18. The result from Fig. 17 shows that the average deflection from Evans and Duncan (1982) [ ] is equal 1.26 the average deflection obtained from the present study. The average deflection from the characteristic load method (1994) is equal 1.21 the deflection obtained from the present study.

For this case, the proposed equation to estimate the pile group deflection is:

$\mathrm{Yg}=0.001 \mathrm{H}^{3}-0.022 \mathrm{H}^{2}+0.5494 \mathrm{H}+0.9024$

The result from Fig.18 shows that the average deflection from Evans and Duncan (1982) is equal 1.42 the average deflection obtained from the present study. The average deflection from characteristic load method (1994) is equal 1.37 the deflection from the present study.

For this case, the proposed equation to estimate the pile group deflection is:

$\mathrm{Yg}=-0.0006 \mathrm{H}^{3}+0.06 \mathrm{H}^{2}-0.4879 \mathrm{H}+1.8429$

Where;

Yg : Max. Group deflection.

$\mathrm{H}$ : Lateral force. 


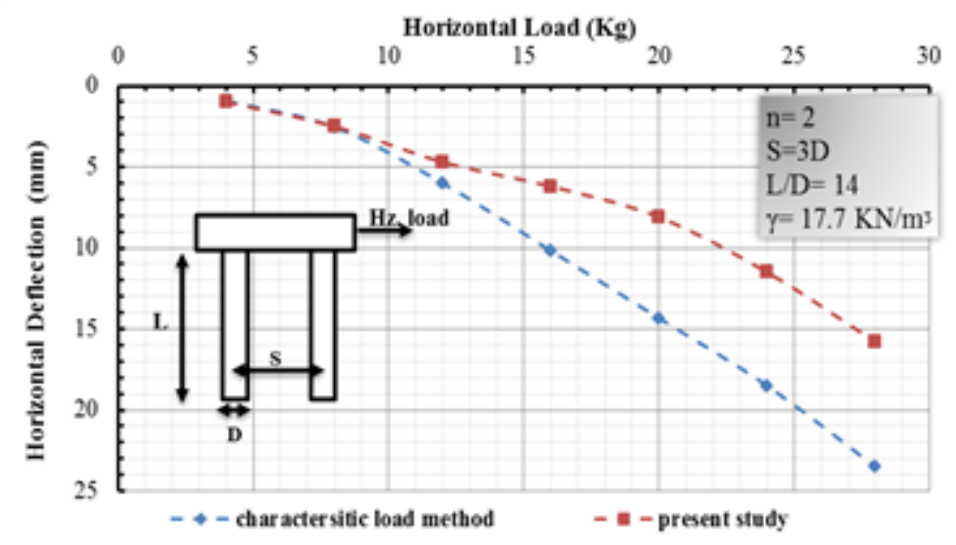

Figure 17. Comparison between deflections by Evans and Duncan, characteristic load method and the present study $\left(\mathrm{L} / \mathrm{D}=14\right.$, number of piles $=2$, spacing between piles $=3$ Dry density $\left.=17.7 \mathrm{kN} / \mathrm{m}^{3}\right)$

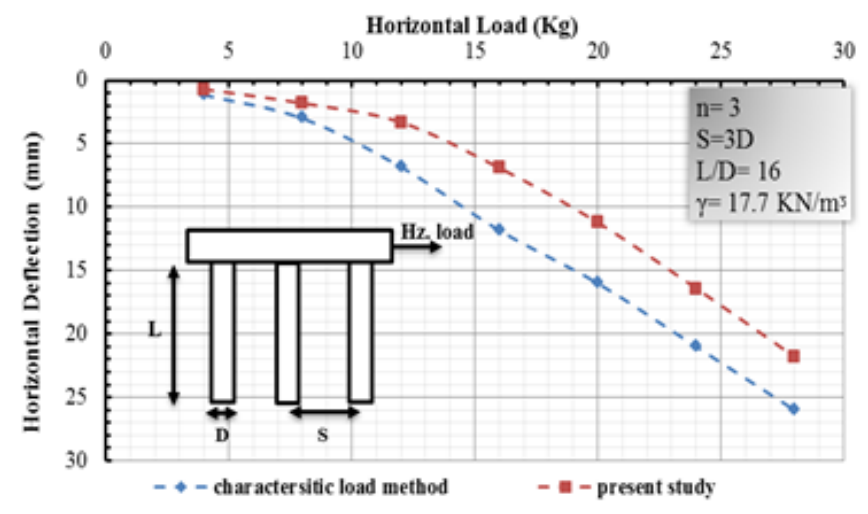

Figure 18. Comparison between deflections by Evans and Duncan, Characteristic load method and the present study $\left(\mathrm{L} / \mathrm{D}=16\right.$, number of piles $=3$, spacing between piles $=3 \mathrm{D}$, dry density $\left.=17.7 \mathrm{kN} / \mathrm{m}^{3}\right)$

\section{SOIL DEFORMATION}

The deformation of the soil surrounding piles depends on its place next to the pile row, it is noticed that each pile pushes the soil behind it creating a shear zone in the soil, these shear zones begin to enlarge and overlap as the lateral load increases especially for the case of closely spaced pile groups. An overlap that occurs between piles in the same row is called "edge effect", while an overlap that occurs between piles in different rows is called "shadowing effect". This overlap in shear zones weakens the soil and results in less lateral resistance per pile. The overlap in shear zones that occurs within a pile group is shown in Fig. 19.

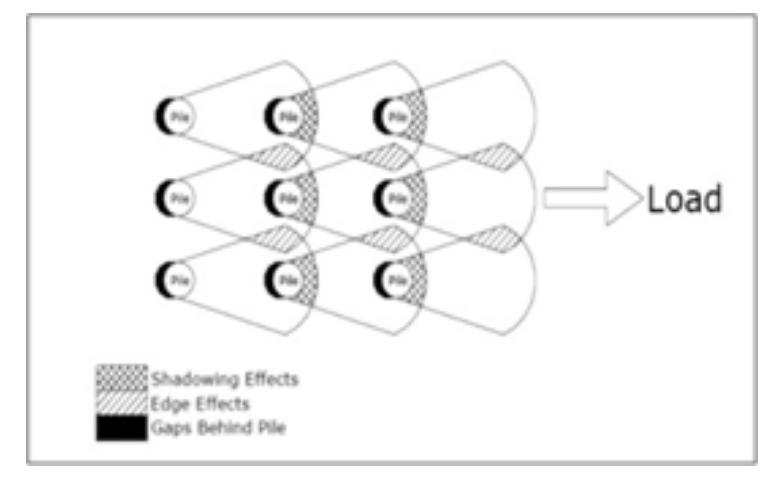

Figure 19. Illustration of shadowing and edge effects in a laterally loaded pile group 
The movements of the soil were measured by putting tracing point on the soil in rows next to the pile and the photos were taken every increment of load. These photos were studied in relation to the initial condition to find the deformation of this rows which represent the movements of soil next to piles, by using digital photogrammetry program. To demonstrate that, Fig.20.is illustrated for $\mathrm{L} / \mathrm{D}=14$, Spacing between piles $=3 \mathrm{D}$, number of piles $=3$, dry density $=18.6 \mathrm{kN} / \mathrm{m}^{3}$.
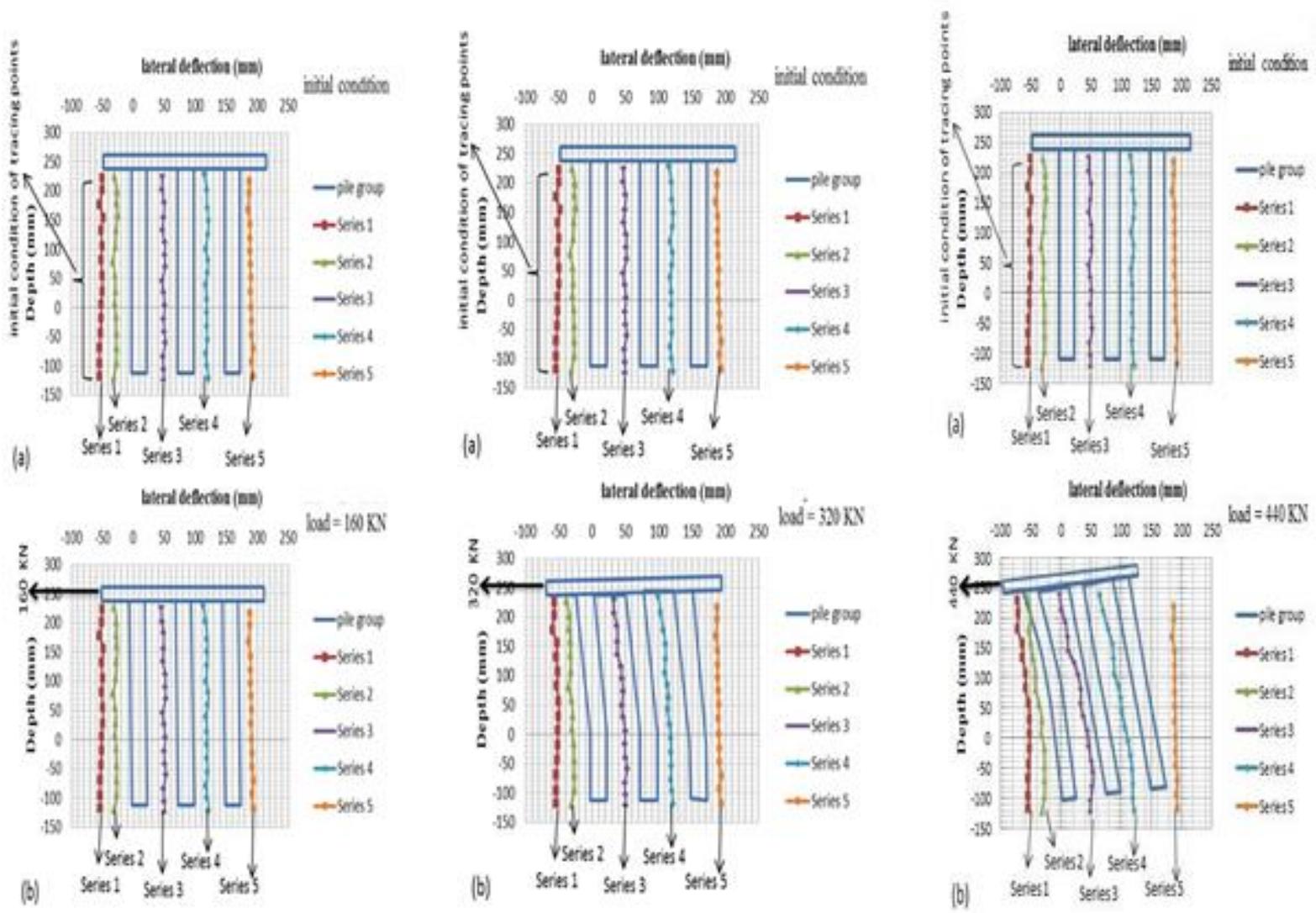

Figure 20. Soil and pile group deformation under lateral loads in comparison to initial condition (L/D $=14$, Spacing between piles $=3 \mathrm{D}$, number of piles $=3$, dry density $=18.6 \mathrm{kN} / \mathrm{m}^{3}$ )

From the present study, it is concluded that increasing the number of piles decreases the deformation of the soil surrounding pile. Increasing of spacing between piles decreases the deformation of the soil surrounding piles, and increasing of soil density decreases the deformation of the soil surrounding piles.

Fig.20. also shows that the deformation of surrounding soil decreases with increasing the depth from ground surface. Also the deformation of the soil next to the leading row is lower than the deformation of the soil next to other rows. That's clear in Fig. 21 which shows the piles arrangement.

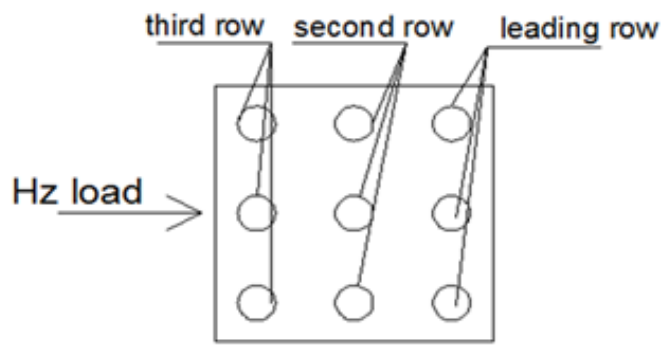

Figure 21. Piles arrangement 


\section{CONCLUSIONS}

Based on the results of the experimental work carried out it is concluded that:

- Increasing of slenderness ratio of piles increase the pile group deflection especially slenderness ratio of 16 for soil density $17.7 \mathrm{kN} / \mathrm{m}^{3}$.

- Sometimes, the piles with small slenderness collapsed faster than the piles with large slenderness.

- Increasing the number of piles, spacing between piles and soil density decrease the pile group deflection.

- Decreasing the number of piles from 3 to 2 , Increasing the pile group deflection ratio for $S=2.5 \mathrm{D}$ is larger than for $\mathrm{S}=3 \mathrm{D}$ for all slenderness ratio except for $\mathrm{L} / \mathrm{D}=16$.

- Decreasing the spacing between piles from 3D to 2.5D, Increasing the pile group deflection ratio for number of piles $=2$ is larger than for number of piles $=3$ for all slenderness ratio except for $\mathrm{L} / \mathrm{D}=16$.

- Decreasing soil dry density from $18.6 \mathrm{kN} / \mathrm{m}^{3}$ to $17.7 \mathrm{kN} / \mathrm{m}^{3}$, increasing the pile group deflection ratio for $\mathrm{N}=2$ for $\mathrm{S}=2.5 \mathrm{D}$ and $3 \mathrm{D}$ were the same, for slenderness ratio 16 .

- Decreasing soil dry density from $18.6 \mathrm{kN} / \mathrm{m}^{3}$ to $17.7 \mathrm{kN} / \mathrm{m}^{3}$, increasing the pile group deflection ratio for $\mathrm{N}=3$ for $\mathrm{S}=2.5 \mathrm{D}$ and $3 \mathrm{D}$ were the same, for slenderness ratio 16 .

- Increasing of number of piles, spacing between piles and soil density decrease the deformation of the piles surrounding soil.

- It is noticed that the deformation of surrounding soil decreasing with increasing the depth from the ground surface.

- It is noticed that the deformation of the soil next to leading row is lower than the deformation of the soil next to other rows.

\section{REFERENCES}

[1] Allersma, H. G. B. 1996. "Using digital image processing in field measurement". Geotechnique, 46. No. 3, pp. 561-563.

[2] Andrawes, K. Z and Butterfield, R. 1973. "The measurement of planar displacement of sand grains". Geotechnique, Vol. 23, No. 5, pp. 571-576.

[3] Attia, M. (2013). "Study of the behavior of pipes and conduits buried in soil." PHD Thesis, Helwan University, Cairo, Egypt.

[4] Butterfield, R., Harkness, R.M., and Andrews, K. Z. (1970). "A stero-photogrammetric method for measuring displacement fields." Geotechnique; 20(3), 308-314.

[5] Duncan, J.M., Evans, L.T.J.R. and Ooi, P.S.K. (1994). "lateral load analysis of single piles and Drilled shafts.” ASCE, Journal of Geotechnical Engineering; 122(6), 1018-1033.

[6] Evans, L.T.J.R. and Duncan, J.M, (1982). "Simplified analysis of laterally loaded piles." Report UCB/GT/82-04, University of California, Berkley.

[7] Hirayama H. (1988), "A Unified Base Bearing Capacity Formula for Piles”, Soils and Foundations; Vol. 105, No. 3.

[8] Rao, S.N., Ramakrishna, V.G.S.T., and Rao, M.B. (1998). "Influence of rigidity on laterally loaded pile groups in marine clay." Journal of Geotechnical and Geoenvironmental Engineering; 124(6), 542-549.

[9] Ticoff, J. 1977. "Surface Footing on Sand Under General Planar Load", Ph.D. Thesis, Southampton Univ, U.K.

[10] White, D. J.; Take, W. A.; and Bolton, M. D. 2003. Soil deformation measurement using particle image velocimetry and photogrammetry. Geotechnique, 53, No. 7, pp. 619-631. 